\title{
Design of Cooperative Activities in Teaching- Learning University Subjects: Elaboration of a Proposal
}

\author{
Norka Bedregal-Alpaca ${ }^{1}$, Víctor \\ Cornejo-Aparicio ${ }^{4}$ \\ Departamento Académico de \\ Ingeniería de Sistemas e Informática \\ Universidad Nacional de San \\ Agustín de Arequipa \\ Arequipa, Perú
}

\author{
Arasay Padron-Alvarez ${ }^{2}$ \\ Centro de Referencia para la \\ Educación de Avanzada \\ Universidad Tecnológica de la \\ Habana \\ La Habana, Cuba
}

\author{
Elisa Castañeda-Huaman ${ }^{3}$ \\ Departamento Académico de \\ Ingeniería Industrial \\ Universidad Nacional de San \\ Agustín de Arequipa \\ Arequipa, Perú
}

\begin{abstract}
University professors face the challenge of incorporating activities that promote student engagement, discussion, conflict resolution, and teamwork. In this context, cooperative learning emerges as the pedagogical model that fosters teamwork; organizes students into groups where joint and coordinated work reinforces individual and collective learning. The proposal presented facilitates the design of cooperative activities that consider the necessary interdependence between learning, teaching, content and context. In addition to explaining how to articulate all these aspects, it also places the student as the center of the training process, for this it collects the main guidelines of cooperative learning and enriches the learning environment with the potential of management knowledge and communication provided by Information and Communication Technologies. To inform the proposal, the results obtained in four subjects of a mathematical nature are presented; results showing improvements in student learning.
\end{abstract}

Keywords-Cooperative learning; competency focus; cooperative techniques; evaluation

\section{INTRODUCTION}

We live in an ever-changing society, accelerated scientific and technological development demands new cultural, economic and production conceptions and marks new forms of work and social relations; therefore, the university must train competent individuals who respond to the requirements of productive structures, live in diversity and act responsibly in the different spheres of life.

Thus, many universities have gone from a traditional model to a more flexible, more effective one in line with the economic, political and cultural demands posed by society. To this end, they have redesigned their educational model under a competency development approach; however, these changes are not always reflected in the teaching practice of their teachers. There are university institutions where the traditional teaching model is used, the teacher transmits knowledge and when the student is asked to create knowledge, the learning process is not valued [1].

To assess the learning process, it is not enough for the teacher to explain topics and propose exams, to take responsibility for change, to look for new teaching strategies that promote not only knowledge acquisition, but also, the development of cross-cutting competences such as coexistence, participation, cooperation, autonomy, self-criticism, ethics and reflection [2]. Within this group of skills, teamwork is perhaps one of the most in-demand, which is why it is part of the learning objectives of university curricula [3], therefore it is necessary to integrate the training process practical practices based on cooperative learning.

There is ample theoretical and practical evidence of the benefits of cooperative learning, however, it is not given the importance it deserves. The reasons are several and diverse, ranging from the little knowledge of the methodology to the possibility of not covering the scheduled contents.

In response to the situation described, the objective of this work is to propose a set of steps to design cooperative activities that motivate the student and serve as an instrument for the achievement of the defined competencies for a subject, for which proposes:

- Place the student as the protagonist of the management of their own learning process.

- Involve the student in the evaluation process.

- Identify the teaching methods that contribute to the achievement of competences.

The proposal considers the white box approach to group work [4], i.e. the teacher interacts with the group as an advisor, supervisor and guide and at times of evaluation takes into account the quality of the work, planning, task sharing, coordination, responsibilities assumed by each team member, etc.

Survey results to gather students' perception of cooperative activities show that they value this methodology is positive because, although it involves them a higher workload, they consider that it forces them to study continuously, day by day, which leads them to a better understanding of the subject, consequently obtain better academic results. 


\section{COOPERATIVE LEARNING (CL)}

In colloquial language the terms collaborate and cooperate refer to a similar concept; etymologically collaborate comes from the latin "co-laborare", "laborare cum" and means working together within a context of help, interest, service and support [5]. This etymological explanation justifies the fact that the concept of "Cooperative Learning" is used interchangeably through terms such as collaborative learning, group work or teamwork.

There are several AC specialists, however, the most representative authors are Johnson and Johnson (around the 1960s), DeVries and Slavin (the 1970s), Slavin and collaborators (late 1970s and early 1980s), Cohen (in the 1990s). In the first decade of the 21st century, as a result of the demands of the European Higher Education Area (EEES), other authors joined.

In order to unify the terminology, the proposition its assumed "Cooperative learning is to use in small group education where students work together to improve their own learning and that of others. Students also feel that they can achieve their learning goals only if the other members of their group also achieve it."

In [7], in relation to cooperative learning is proposed ". we could consider it as a learning system in which the purpose of the academic product is not exclusive, but displaces it in search of the improvement of one's own social relationships, where to achieve both academic objectives and relational; group interaction is emphasized."

\section{A. Why Include Cooperative Learning Techniques?}

The use of methodologies such as CL is an alternative practice to traditional teaching whose effectiveness has been demonstrated in several studies [8]. Thus, this article proposes as a solution to the problem identified.

The CL allows to attend the student's training process and consider the competencies as the axis to move from a process focused on the appropriation of knowledge to a process that seeks the student to apply what is learned in specific situations [9]. It is a way to change teaching practice and adapt it to the new educational model; the path in which teamwork is one of the most important competencies, to ensure that students develop teamwork skills it is necessary to include structured activities that improve learning outcomes and develop defined competencies.

Among the most important consequences of working on a skills approach is the need for methodological renewal [10], including the use of active methodologies [11] that provide meaningful learning.

$\mathrm{AC}$ is an effective methodology for the development of both critical sense and tolerance, when the task is complex or when the social development of students is desired [12]. The incorporation of $\mathrm{AC}$ techniques in higher education in addition to fostering intellectual skills in the student allows the development of positive values and attitudes that will allow him to perform competently in his future professional practice.
The CL transcends academia and facilitates the development of cross-cutting competences (such as cooperation, solidarity and group work) that are in high demand by business systems. According to [13], between 70 and $80 \%$ of the work requires complex coordination of ideas and efforts, a capacity that can only be developed and experienced through CL situations.

Active methodologies, within a given context, allow to develop knowledge, skills, skills and attitudes. The importance of these methodologies lies in the generation of more active, motivating and inclusive teaching-learning environments that by placing the student as the protagonist of their learning process promote their autonomy and participation. Within active methodologies, cooperative learning is the basis for all others to be properly developed (Table I).

TABLE. I. COOPERATIVE LEARNING AS THE BASIS FOR DEVELOPING OTHER ACTIVE METHODOLOGIES

\begin{tabular}{|l|l|l|}
\hline Methodology & Building learning & $\begin{array}{l}\text { Working } \\
\text { mode }\end{array}$ \\
\hline $\begin{array}{l}\text { Problem- } \\
\text { Based }\end{array}$ & $\begin{array}{l}\text { Based on a problem situation, students define } \\
\text { the problem, characterize it, and propose a } \\
\text { solution }\end{array}$ & \\
\cline { 1 - 2 } $\begin{array}{l}\text { Project-based } \\
\text { learning }\end{array}$ & $\begin{array}{l}\text { Based on the need for a final product, students } \\
\text { propose and execute an action plan to reach } \\
\text { the solution }\end{array}$ & \\
\cline { 1 - 2 } $\begin{array}{l}\text { Case-based } \\
\text { learning }\end{array}$ & $\begin{array}{l}\text { Based on a particular situation, students make } \\
\text { decisions on a set of decision alternatives }\end{array}$ & \\
\cline { 1 - 2 } $\begin{array}{l}\text { Service } \\
\text { Learning }\end{array}$ & $\begin{array}{l}\text { Based on a social issue, students apply prior } \\
\text { knowledge to design and implement a solution }\end{array}$ & \\
\cline { 1 - 2 } $\begin{array}{l}\text { Game-based } \\
\text { learning }\end{array}$ & $\begin{array}{l}\text { Games are used, already created or invented } \\
\text { for a specific purpose, in order for the student } \\
\text { to learn through them. The game is the vehicle } \\
\text { to strengthen concepts. }\end{array}$ & \\
\hline
\end{tabular}

\section{Context And PRoblem Detected}

The proposal, subject of this work, is a consequence of the problems observed at the National University of San Augustin de Arequipa (UNSA); problem that is shared by other university cloisters. In 2016, UNSA assumes a new educational model with a focus on skills development, since then, the academic vice-chancellor has taken a number of measures in order to ensure that the training processes respond to this model.

However, the starting situations that lead us to present this proposal can be specified in the following points:

- While the curricula of the different specialties have defined exit competencies as the axis of the curriculum, in practice there is no awareness among teachers of the methodological transformation that this entails.

- Generally, in teaching practice, traditional methodologies (professor-centered) based on verbal transmission of content continue to dominate, in which the evaluation is based on the reproduction of what has been learned. 
- The practice of assigning group work as a teaching methodology is being generalized, however, the expected results are not achieved either in the appropriation of knowledge or in the development of skills. Usually students distribute the assignments, perform them individually, then gather all the parts and deliver the final product.

\section{PROPOSAL}

University professors, who have generally not been trained in pedagogy, face new challenges in their teaching practice. The experience gained over the years in its role as a knowledge transmitter is no longer sufficient [14]. Today they are challenged to enhance the ability to learn in students.
Therefore, the professor needs tools that allow him to develop his teaching practice by giving the student greater prominence, to do so he must implement actions that promote student participation, teamwork and the ability to debate and resolve conflicts reasoned [15].

The design of a cooperative activity involves considering the interdependence that must exist between the cooperative model, learning, teaching, content and context; that is why, in Fig. 1 (at the end of the document), a model is proposed that explains to teachers how to articulate all these aspects.

The proposed model places the student as the center of the training process, is based on the main guidelines of cooperative learning and uses the potentials knowledge management and communication of ICT to enrich the environment learning.

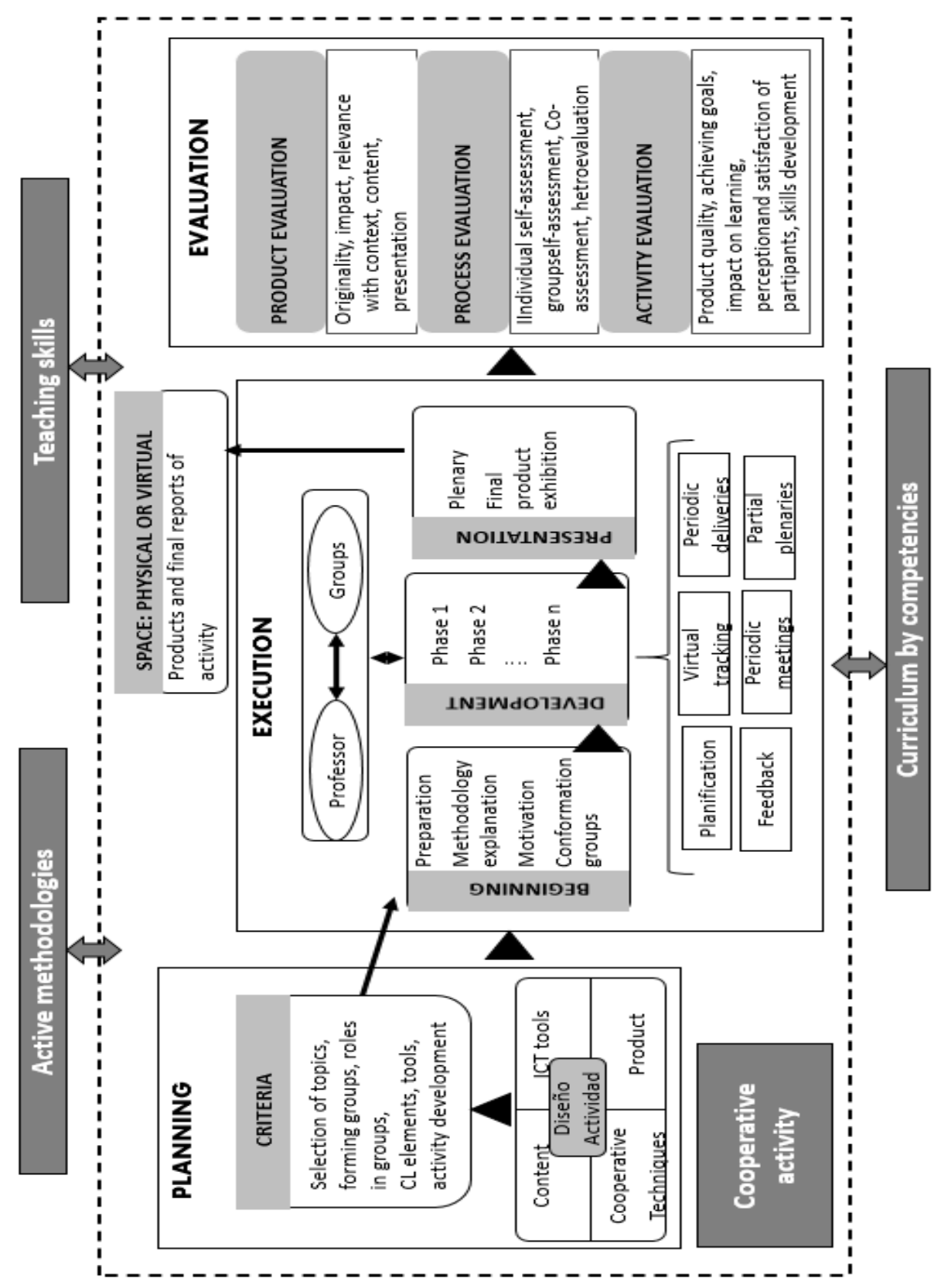

Fig. 1. Model for the Design of Cooperative Activities. Own Elaboration. 
Teaching within the framework of a competency curriculum involves the need for methodological changes (use of active methodologies) that make the student an active component in the learning process, thus increasing the teacher's pedagogical background (teaching skills); in this context, as seen in the model, a cooperative activity becomes a binding element.

The proposed model has three main components: the design of the cooperative activity, the execution of it and the evaluation of what has been done.

\section{A. Design of Cooperative Activity}

Academic activities are the set of operations carried out within the framework of teaching-learning processes, which are aimed at fostering knowledge, developing skills and connecting the student with their field of work.

It is essential to plan the activities that can be carried out during the development of a subject, it can be an activity that integrates the main topics of the syllabus or it can be smaller activities related to a chapter or a topic in Particular. Whatever the case may be, proper planning in addition to fostering direct contact between teachers and students will not only allow students to appropriate knowledge will also serve to be used creatively in practice daily.

In the design of the activity based on cooperative learning, the teacher assumes the role of instructional designer, in that sense it is recommended to take into account:

- The planning of the activity begins with the definition of a purpose or a goal.

- Choose the contents, the skills that are expected to be developed and the evaluation criteria to be established must be determined.

- Specify the learning results that the student is intended to achieve. They should refer to relevant learnings, i.e. those that are necessary for the student to continue their training process.

- Choose ICT tools that enhance communication, information search and knowledge management. With the support of a virtual educational platform it is convenient to use email, forums, distribution lists, chats, blogs, wikis, webcam, etc.

- Determine the resources necessary for the realization of the activity.

- Establish the minimum characteristics that the product of the activity must have, for this it should be borne in mind that the activity is a training process that completes the theoretical-practical training of the students.

- Estimate the time required for the performance of the activity and define phases or moments in the execution.

- Divide the activity, if necessary, into sub activities.

With the above considerations, the next step is to design the cooperative environment for this purpose, the group with which it is to work must be taken into account; the teacher must know its particularities, their level of preparation and degree of maturity, since these characteristics determine the performance of the students.

Activities, which are carried out in groups or teams, are cooperative when a number of conditions occur, known as elements of cooperative learning:

1) Heterogeneous groupings.

2) Positive interdependence.

3) Individual and group responsibility.

4) Equal opportunities for success.

5) Promoter interaction.

6) Cognitive processing of information.

7) Use of cooperative skills.

8) Individual and group evaluation.

The cooperative triad must be articulated as a measure of the quality of cooperation, i.e. three aspects (a) That the members of the group are needed of each other to achieve the objective (positive interdependence), (b) That everyone can participate (fair participation) and (c) That can be checked whether each member did the work entrusted (individual responsibility).

Cooperative activities generate positive interdependence among its members, i.e. that all members of a group are connected in such a way that they can only achieve success if the other members do so as well. Each group member's task depends on the contributions of the others, then the task must be designed so that they must work together to achieve the ultimate goal. Positive interdependence takes in different forms: goals, tasks, resources, rewards, identity, outsider rivals, and functions.

\section{B. Maintaining the Integrity of the Specifications}

Groups should be heterogeneous in terms of skill, personality, academic performance, gender. It is recommended that the groups conform to the teacher, especially when students have no experience in working cooperatively.

The number of members will depend on the goals set, the ages and experience of the students and the time available. Cooperative learning groups generally have between two and six members, small groups (four people) work best. Different strategies for training them are proposed in [16]. Role distribution implements interdependence with respect to roles, to do this, assigning group members roles that are complementary and interconnected. It is possible to distinguish between two types of roles, those necessary to consolidate and reinforce teamwork and those necessary for the training and operation of the team. In [6] a 7-step proposal is made to work these roles.

From the experience of the authors, three roles are proposed to reinforce teamwork: academic manager, innovation manager and editor-in-chief, roles that have been worked on in [17] and [18].

In order for the activity to be performed among all members of the group, the roles must be rotated. Likewise, to 
ensure group interaction under a positive attitude, it is important to establish the rules of behavior within the groups.

\section{Execution of Cooperative Activity}

This is the time when cooperation is managed, communication between the teacher and the working groups is important, only in this way can cooperative activities be managed and monitor the implementation of them.

At this stage the teacher's performance is extremely important, in addition to forming the groups and choosing the cooperative techniques to employ, he must assume two roles: that of instructor and that of cognitive mediator.

The formation of the groups will be done according to the criteria established in the design of the activity. For the choice of cooperative techniques, [19] describes the characteristics, purpose and time of application of simple cooperative structures and complex cooperative structures is recommended.

In the role of instructor, the teacher must perform traditional activities such as making a methodological explanation of the activity, that is, explaining the activity, its cooperative nature and the skills necessary to execute it.

Motivation is also important, as it predisposes the group to carry out the activity, not only for the academic purpose but also for its relevance to the context and for the development of social skills.

If students do not have experience in cooperative work it is necessary to teach them to work cooperatively, especially when the activity integrates all the content of the subject. To this end, it is appropriate to propose some general-purpose activity with instructional elements that promote an approach to what a team means and that in addition strengthen interpersonal relationships between the team members [20]. This general activity also aims to determine which cooperative techniques are most appropriate for the group considering the phase of the activity being worked on.

For monitoring the realization of the activity, it can follow the procedure proposed by [21] which consists of checking if students are working together, checking if they are doing the job well, and giving feedback. In this framework, the model proposes a set of activities: planning, virtual monitoring, periodic deliveries of progress and regular meetings with each group separately.

Depending on the size of the activity, in each phase of the activity, partial plenaries may be held between all groups to exchange experiences; it's time to turn to the forums provided by a virtual platform.

As a cognitive mediator, the teacher is responsible for helping students develop reasoning skills (critical thinking, problem solving, metacognition) and become independent in managing their learning (learning).

In [22] it has been found that the repetitive use of his "peerto-peer" technique leads to a remarkable performance of higher-order thinking skills; in this technique it asks students a group of incomplete questions that they must answer, for example:

- What is the main idea of...?
- What if...?

- How does it affect ...?

- Why is it important...?

- How does it relate... with what you've learned before?

- What conclusions can be drawn from...?

After the activity is completed, the product of the activity must be made known; what can be done in a plenary session in which each group sets out the result of its work (report, mockup, video, etc.).

It is motivating for students that the product of the cooperative activity can be seen by agents outside the working group, so a physical or virtual space can be enabled for it.

\section{Evaluation of Cooperative Activity}

Continuing his role as an instructor, the teacher should design an evaluation system that defines the events or actions to be observed and evaluated and when those observations will be made.

In the proposed model, the evaluation takes into account three aspects: the product resulting from the activity, the process followed for its elaboration and the activity itself.

The evaluation of the product is closely related to the achievement of the proposed educational objectives, considers the application of the contents to real or near-reality situations, as well as their relevance and relevance.

To promote the development of cross-cutting competencies, also called soft skills, (leadership, interpersonal communication, time management, work under pressure, among others) the presentation and livelihood of the final product should be evaluated.

To assess students' perception and satisfaction in relation to cooperative activity, an online tool can be used to implement a questionnaire, with four-level Likert-like questions, which consider the dimensions proposed in Table II.

Evaluation should be an ongoing process, integrated into teaching and learning processes whereby students are assessed attaining goals and processes can be refocused, adapting them to specific needs and changing students.

The evaluation is the most controversial element of the CL, some authors propose that the evaluation be group and others should also be individual. However, everyone agrees that group evaluation serves to regulate the group's performance.

In a cooperative activity, the evaluation of activities can be planned at various stages of the process and can be done by: the teacher, the student, or the members of the group.

To define indicators, the evaluation system must consider two types of evaluation: continuous and summative (Table III).

At this point it is important that students know, from the beginning of the cooperative activity, the times when the evaluation will be given, the products or situations to be evaluated and the tools that will guide the process. 
TABLE. II. DimENSIONS TO AsSESS STUDENTS' PERCEPTION

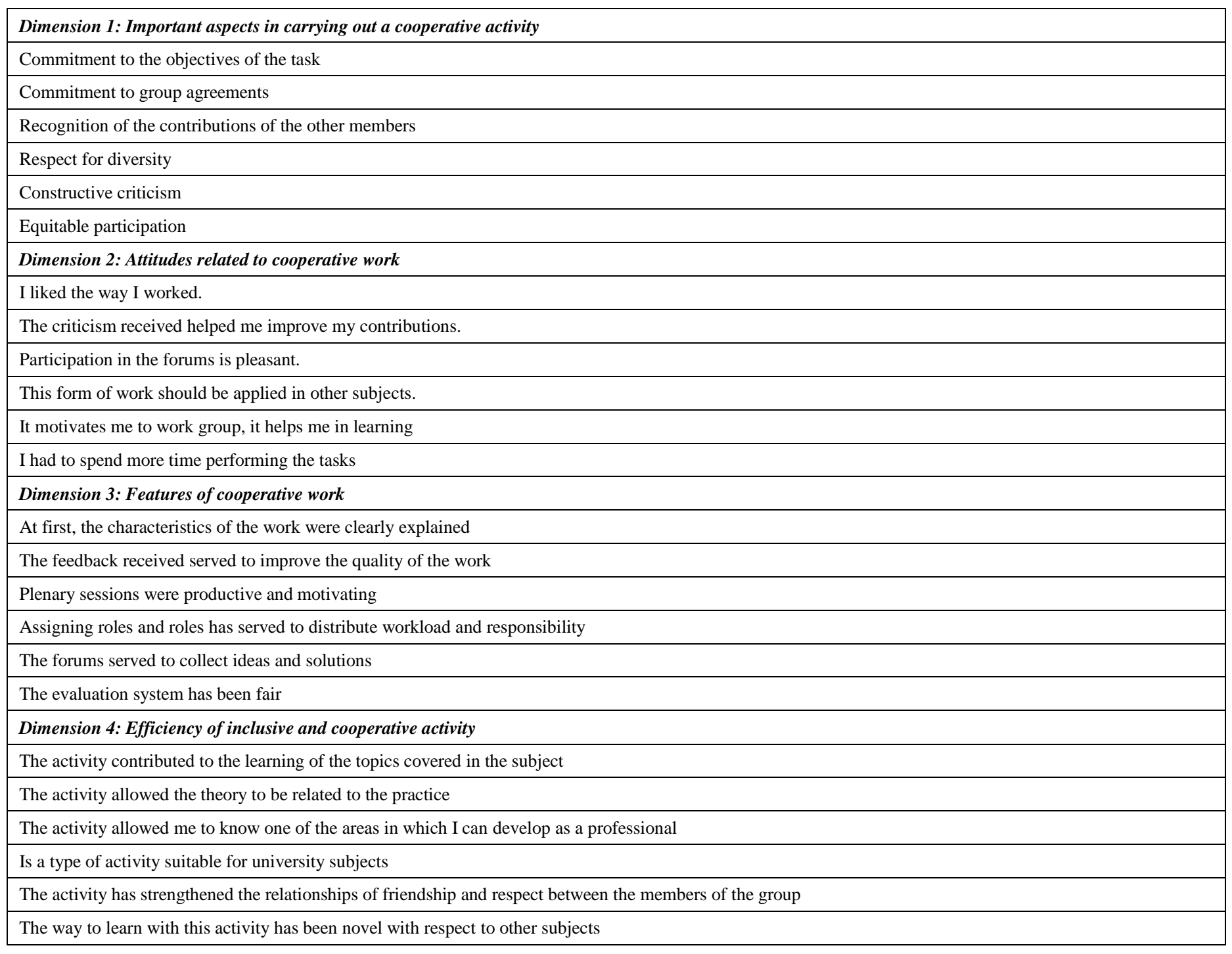

TABLE. III. INDICATORS AND TYPES OF EVALUATION

\begin{tabular}{|l|l|l|l|}
\hline Dimension & Indicator & Type Evaluation & Instrument \\
\hline Group process & $\begin{array}{l}\text { Group identity } \\
\text { Activity planning } \\
\text { Assigning roles, roles, and tasks } \\
\text { Feedback between members }\end{array}$ & $\begin{array}{l}\text { Continuous evaluation } \\
\text { Group self-assessment } \\
\text { Coevaluation } \\
\text { Heteroevalua-tion }\end{array}$ & $\begin{array}{l}\text { Questionnaire with opinion scales } \\
\text { Co-evaluation form } \\
\text { Group process observation guides }\end{array}$ \\
\hline Individual performance & $\begin{array}{l}\text { Acquired knowledge } \\
\text { Skills demonstrated } \\
\text { Attitude towards colleagues and group work }\end{array}$ & $\begin{array}{l}\text { Individual self-assessment } \\
\text { Continuoustionnaire with opinion scales }\end{array}$ & Quation \\
\hline Product quality & $\begin{array}{l}\text { Mastery of concepts and procedures } \\
\text { Proper application of concepts and procedures }\end{array}$ & $\begin{array}{l}\text { Continuous evaluation } \\
\text { Heteroevalua-tion }\end{array}$ & $\begin{array}{l}\text { Face-to-face exams } \\
\text { Virtual questionnaires } \\
\text { Interventions in forums and plenaries }\end{array}$ \\
\hline & $\begin{array}{l}\text { Meets originally requested } \\
\text { Group reflection on product quality }\end{array}$ & $\begin{array}{l}\text { Summative assessment } \\
\text { Group co-assessment } \\
\text { Heteroevalua-tion }\end{array}$ & $\begin{array}{l}\text { Rubric to assess product quality } \\
\text { Checklist }\end{array}$ \\
\hline
\end{tabular}




\section{RESUlTS OBTAINED}

The proposal that has been presented is the result of the inclusion of cooperative learning in subjects in the area of engineering.

Subjects of a mathematical nature were worked, so a first version of the proposal was worked on in the subject "Operational Research" [17], improvements were made to the proposal to design cooperative activities in the subject "Mathematics Discrete" [18]. This improved version was applied in the construction of a video library in the subject "Numerical Methods" [23].

The proposal was also used to implement a cooperative task under the project-based learning methodology in the subject "Product Engineering" [24].

Table IV compares the grades obtained in the semester in which the proposal is applied (grey boxes) with those obtained in the previous semester (blank boxes).

In all cases, improvements in grades can be seen, a situation that is reinforced by students' perception of the benefits gained from working cooperatively.

It is worth clarifying that the management of cooperative tasks designed following the proposed methodology was facilitated with the use of the Moodle platform as a repository and as a means of communication and knowledge management; [25] an assessment of student perception regarding the use of the Moodle platform is made from the perspective of the TAM (Technological Acceptance Model).

TABLE. IV. COMPARISON OF THE GRADES OBTAINED

\begin{tabular}{|l|l|l|l|}
\hline Subject & Average & Dev. standard & \%approved \\
\hline \multirow{2}{*}{$\begin{array}{l}\text { Operational } \\
\text { Research }\end{array}$} & 12.25 & 2 & 72 \\
\cline { 2 - 4 } & 13.15 & 1.5 & 90 \\
\hline $\begin{array}{l}\text { Discrete } \\
\text { Mathematics }\end{array}$ & 11.2 & 1.84 & 65.71 \\
\cline { 2 - 4 } & 12.5 & 1.90 & 77.5 \\
\hline $\begin{array}{l}\text { Numerical } \\
\text { Methods }\end{array}$ & 10.45 & 2.49 & 53 \\
\cline { 2 - 4 } & 12.54 & 2.45 & 89 \\
\hline $\begin{array}{l}\text { Product } \\
\text { Engineering }\end{array}$ & 14.3 & 2.23 & 75 \\
\cline { 2 - 4 } & 15.4 & 2.05 & 82 \\
\hline
\end{tabular}

\section{CONCLUSIONS}

For the success of the proposed model it is necessary to articulate three central aspects: cooperative learning as a pedagogical model, the design of a motivating activity and that relates theory with practice and evaluation of the act.

The activities that integrate theory and practice and that are carried out in a cooperative way promote the development of the capacities demanded by today's society.

Using cooperative learning as the basis for the implementation of other active methodologies places the student as the center of the teaching and learning processes; in this context, learning is no longer passive by performing group tasks that contribute to the development of learning capacity throughout life.
The evaluation should be relevant to the cooperative learning model, it cannot be based solely on traditional tests, but rather on products that show the level of achievement of learning outcomes.

Implementing cooperative activities does not mean that the development of the subject is always organized in cooperative groups. The combination of the masterful activity developed by the teacher and one or more cooperative activities is required. The teacher will find a balance between them.

The design of integrative activities based on cooperative techniques requires that the teacher, in addition to mastering the subject, also has the ability to coordinate, guide and enhance the individual and team work of the students. It is not only a question of scheduling cooperative activities, but of incorporating cooperation into the usual dynamics of classes, in order to get students to work systematically as a team and internalize cooperative skills.

The proposed way of working is participatory, interactive and different, breaks with the usual method of teaching and fosters interpersonal relationships becoming an incentive for collective learning.

\section{ACKNOWLEDGMENT}

The authors' thanks are expressed to the National University of San Augustin de Arequipa for the support received in the realization of the proposal and the results are expected to benefit the institution.

\section{REFERENCES}

[1] A. Fidalgo-Blanco, M. Sein-Echaluce, F. García-Peñalvo, "Inteligencia Colectiva en el aula. Un paradigma cooperativo", IV Congreso Internacional sobre Aprendizaje, Innovación y Competitividad (CINAIC 2017), 2017. DOI: 10.26754/CINAIC.2017.000001_125.

[2] J. De Pablos, "Los medios como objeto de estudio preferente para la tecnología educativa", Universidad de Sevilla, 2000. Consultado HTTP://WWW.LMI.UB.ES/TE/ANY96/DEPABLOS_CEDECS/.

[3] D. Lerís, A. Fidalgo and M. Sein-Echaluce, "A comprehensive training model of the teamwork competence". Int. J. Learn. Intellectual Capital, 11, 1-19, 2014. DOI 10.1504/IJLIC.2014.059216.

[4] A. Fidalgo, "Trabajo en equipo. Caja negra versus Caja blanca" Innovación Educativa [online], 2007. http://innovacioneducativa. wordpress.com/2007/04/25/trabajo-en-equipocaja-negra-versus-cajablanca/.

[5] J. Corominas and J. Pascual, "Diccionario crítico etimológico castellano e hispánico", Madrid: Gredos, 2007.

[6] D. Johnson and R. Johnson, "Aprender juntos y solos", Buenos Aires: Aique Grupo Editor, S.A, 1999.

[7] Linares, "El aprendizaje cooperativo en habilidades sociales para la mejora de la convivencia en los centros", Consejería de Educación y Cultura Dirección General de Formación Profesional e Innovación Educativa Centro de Profesores y Recursos de Cieza, 2006.

[8] R. Slavin, "Instruction based on cooperative learning”, En R. Mayer (Ed.), Handbook of research on learning and instruction (pp. 344-361). London: Taylor \& Francis, 2011.

[9] A. Zabala and L. Arnau, "11 ideas clave: cómo aprender y enseñar competencias”, Barcelona: editorial Graó, 2007.

[10] A. Fernández, "Metodologías activas para la formación de competencias", Revista Educatio siglo XXI [en línea], 24, pp. 35-56, 2006.

[11] C. Gil, R. Baños, A. Alías and M. Gil, "Aprendizaje cooperativo y desarrollo de competencias", En Simón, M.A., González, M.L. y Vivaracho, C.E. (Eds) $7^{\mathrm{a}}$ Jornadas sobre aprendizaje cooperativo, pp. 6372. Valladolid: Universidad de Valladolid, 2007. 
[12] A. Macpherson, "Cooperative Learning Group Activities for College Courses”, Surrey, BC Canada: Kwantlen Polytechnic University, 1999, 2015.

[13] P. Colás, "La investigación-acción aprendizaje cooperativo como propuesta de innovación metodológica en el aula universitaria", Revista de Enseñanza Interuniversitaria, 5, 83-97, 1993.

[14] M. Burguet and M. Buxarrais, "La eticidad de las TIC. Las competencias transversales y sus paradojas", Revista Teoría de la Educación: Educación y Cultura en la Sociedad de la Información, 14(3), 87-100, 2013.

[15] M. Buxarrais and E. Ovide, "El impacto de las nuevas tecnologías en la educación en valores del siglo XXI", Sinéctica, 37, 2011.

[16] S. Kagan, "Cooperative learning", San Juan Capistrano, CA, Kagan Cooperative Learning, 1992.

[17] N. Bedregal, "Cooperative learning using Moodle as a support resource: Proposal for continuous evaluation in operational research", Proceedings - International Conference of the Chilean Computer Science Society, SCCC. Volume 2017-October, 5 July 2018, Pages 1-9. 2018. DOI: 10.1109/SCCC.2017.8405131.

[18] N. Bedregal, D. Tupacyupanqui and V. Cornejo, "Video and cooperative work as didactic strategies to enrich learning and development of generic competences in Numerical Methods",. LACLO 2018, XIII Latin American Conference on Learning Technologies, Brasil, 2018. DOI: 10.1109/LACLO.2018.00038.

[19] S. Kagan, "Kagan Structures and Learning Together. What is the Difference?". Kagan Online Magazine, 2001.
[20] L. Bellamy, D. Evans, D, Linder, B. McNeill and G. Raupp, "Teams in Engineering Education", Report to the National Science Foundation on Grnat Number USE9156176, Tempe, AZ, Arizona State University, 1994.

[21] D. Johnson, "Cooperation in the Classroom", Interaction Book Company, Seventh Edition, 1998.

[22] A. King, "From sage on the stage to guide on the side", College Teaching, 41 (1): 30-35, 1993.

[23] N. Bedregal-Alpaca, D. Tupacyupanqui-Jaén y V. Cornejo-Aparicio. 1-5 Oct. 2018. Video and cooperative work as didactic strategies to enrich learning and development of generic competences in numerical methods. 2018 XIII Latin American Conference on Learning Technologies (LACLO). São Paulo, Brazil, Brazil. DOI: 10.1109/LACLO.2018.00038.

[24] N. Bedregal-Alpaca1, E. Castañeda-Huamán y O. Sharhorodoska. 2019. Cooperative learning as the basis of an integrating activity in the subject "Product Engineering", V Congreso Internacional sobre Aprendizaje, Innovación y Competitividad (CINAIC 2019) DOI: 10.26754/CINAIC.2019.0050.

[25] N. Bedregal-Alpaca, V. Cornejo-Aparicio, D. Tupacyupanqui-Jaén, S. Flores Silva. Evaluación de la percepción estudiantil en relación al uso de la plataforma Moodle desde la perspectiva del TAM. Ingeniare. Revista chilena de ingeniería. versión On-line ISSN 0718-3305. 2018. DOI 10.4067/S0718-33052019000400707. 